\title{
The selenium status of grazing herbivores in different regions of Southern Africa
}

\author{
J. B. J. van Ryssen \\ Dept of Animal and Wildlife Sciences, University of Pretoria, 0002 Pretoria, South Africa \\ E-mail:jvryssen@postino.up.ac.za
}

Although a substantial amount of information is available on the selenium status of grazing animals in southern Africa, this information has not been mapped to give a clear view of the situation at a glance. In this presentation data available to the author have been used to produce a map of the selenium status of grazing animals. The objective is not only to put together available data, but also to identify areas were little or no information is available, and to encourage surveys to be conducted in these areas to clarify the situation.

\section{Materials and Methods}

Data have been collected from published articles (in list of references) as well as from some unpublished reports.

\section{Results and Discussion}

Figure 1 illustrates the selenium status of grazing animals in certain regions in South Africa. Low concentrations of selenium, indicating deficiencies, have been reported for the eastern and southern parts of the country (Van Niekerk, 2000; van Ryssen, 2000). These areas have a relatively high rainfall and acid soils, conducive to a low selenium uptake by plants (Higgins \& Fey, 1993). However, blood analyses from livestock on the experimental farm of the University of Natal east of Pietermaritzburg indicated an adequate intake.

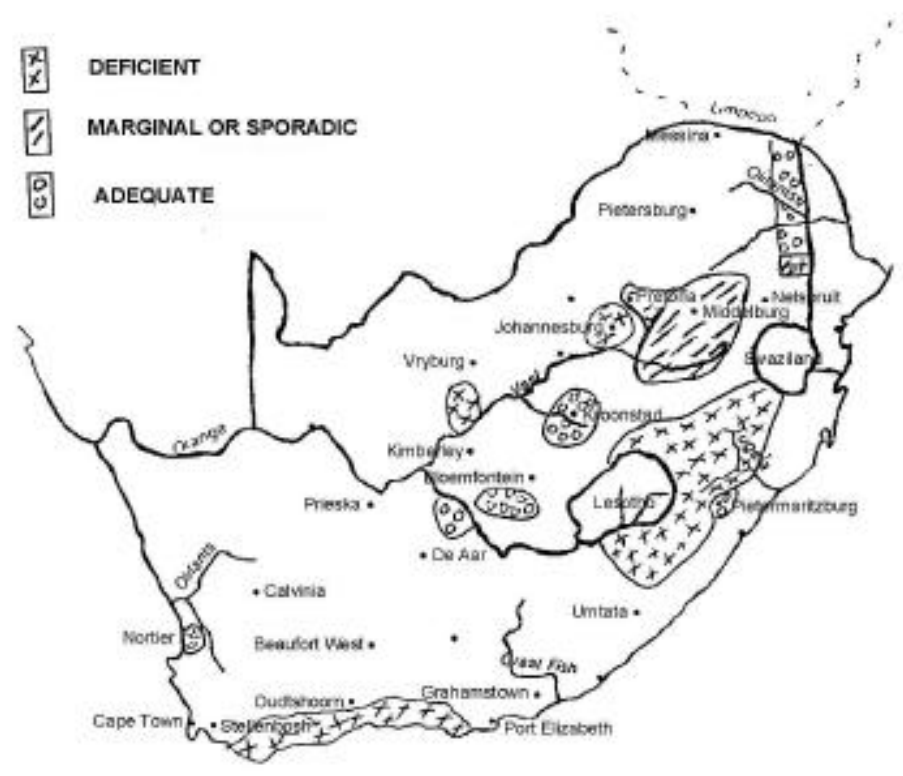

Figure 1 Map of areas of selenium status grazing animals in South Africa

The concentration of selenium in the livers of Buffalo in the southern part of the Kruger National Park indicated a deficiency, but not those in the Northern regions (Erasmus, 2000, unpublished). The selenium concentration in tissues from sheep in the highland sourveld of Mpumulanga and the Northern Free State varied from low to adequate in different areas (Erasmus \& Faanhof, 1983; Haswell, 1997). Cattle grazing the cultivated pastures of the Johannesburg Municipality farms have to be supplemented with selenium (Ehret et al., 1989). Selenium concentrations as low as $12 \mathrm{ng} / \mathrm{g}$ DM have been measured in lucerne from the Vaalhartz irrigation scheme (unpublished results) and could be the reason for deficiencies observed in zoo animals (Ebedes, personal communication). The few studies that covered the drier western parts of the country usually indicated an adequate 
Short paper and poster abstracts: $38^{\text {th }}$ Congress of the South African Society of Animal Science intake of selenium (Erasmus, 1983, 1984; Van Niekerk et al., 1990; Hoon, 1999, unpublished). Mpofu et al. (1999) measured low concentrations of selenium in the blood of cattle in the Sanyati area of Zimbabwe and adequate concentrations in cattle in the Chinambora smallholder grazing area. Little or no information could be obtained from the Transkei and the northern parts of the Eastern Province, Lesotho, Swaziland and surrounding areas in Mpumulanga and high rainfall areas in Venda. The type of soils and rainfall in these areas are similar to those in the selenium-deficient areas of Natal, and deficiencies are quite likely to occur. Little or no information is apparently available on the situation in the bushveld areas of Zululand, the Northern and North Western Provinces, most parts of the Northern Cape, the Karoo and Namaqualand.

\section{Conclusions}

This report suggests that survey-type studies could be conducted in a number of areas of the region. Researchers and personnel at analytical laboratories should also be encouraged to report available information.

\section{References}

Ehret, W.J., Meltzer, D.G.A., Mulders, M.S. \& Collett, F.A., 1989. Erythrocyte glutathione peroxidase activity as an indicator of selenium status in an intensively-managed beef herd. J. S. Afr. Vet. Assoc. 60, 130.

Erasmus, J.A., 1983. Blood selenium levels in unthrifty lambs in the Kroonstad district. J. S. Afr. Vet. Assoc. 54, 210.

Erasmus, J.A., 1984. Blood selenium levels of sheep in some districts of the Northern Orange Free State: The Bultfontein area. J. S. Afr. Vet. Assoc. 55, 115.

Erasmus, J.A. \& Faanhof, A., 1983. Blood selenium of sheep in some districts of the Northern Orange Frre State: A preliminary report. J. S. Afr. Vet. Assoc. 55, 187-188.

Haswell, B., 1997. Micro mineral inadequacies of sheep in the Eastern Transvaal Highveld. Proc. $35^{\text {th }}$ SASAS Congress, Nelspruit.

Higgins, S.P. \& Fey, M.V., 1993. Selenium in some grass pastures of Natal and fertilized-induced Se uptake by ryegrass (Lolium multiflorum). S.Afr.J. Plant Soil. 10, 188.

Mpofu, I.D.P. , Ndlovu, L.R. \& Casey, N.H., 1999. The copper, cobalt, iron, selenium and zinc status of cattle in the Sanyati and Chinamhora smallholder grazing areas of Zimbabwe. Asian-Aus. J. Anim Sci. 12, 579.

O'Hagan, E.D., 1994. An investigation of the selenium status in dairy cows in the Natal Midlands. MSc Agric thesis, University of Natal.

Van Niekerk, F.E., Cloete, S.W.P., Van der Merwe, G.D., Heine, E.W.P. \& Scholtz, A.J. 1995. Parenteral copper and selenium supplementation of sheep on legume-grass pastures: biochemical and production responses in lambs to maternal treatment. J. S. Afr. Vet. Assoc. 66, 11.

Van Niekerk, F.E., Cloete, S.W.P. \& Brand, S.A., 1990. Plasma copper, zinc and blood selenium concentrations of sheep, goats and cattle. S. Afr. J. Anim. Sci. 20, 144.

Van Ryssen, J.B.J. \& Bradfield, G.D., 1992. An assessment of the selenium, copper and zinc status of sheep on cultivated pastures in the Natal Midlands. J. S. Afr. Vet. Assoc. 63, 156-161.

Van Ryssen, J.B.J., Bradfield, G.D., van Malsen, S. \& de Villiers, J.F., 1992. Response to selenium supplementation of sheep grazing cultivated pastures in the Natal Midlands. J. S. Afr. Vet. Assoc. 63, $148-155$.

Van Ryssen, J.B.J., Coertze, R.J. \& de Villiers, J.F., 1992a. Supplementation of selenium to sheep grazing kikuyu or ryegrass I. Selenium status of unsupplemented sheep and animal performance upon supplementation. S. Afr. J. Anim Sci. 29, 137-144.

Van Ryssen, J.B.J. Coertze, R.J. \& de Villiers, J.F., 1992b. Supplementation of selenium to sheep grazing kikuyu or ryegrass II. Effect on selenium concentration in grass and body tissues. S. Afr. J. Anim Sci. 29, 145153. 